\title{
ŻYCIE BRATERSKIE ORAZ ŻYCIE BRATERSKIE WE WSPÓLNOCIE W INSTYTUTACH ŻYCIA KONSEKROWANEGO I STOWARZYSZENIACH ŻYCIA APOSTOLSKIEGO
}

Treść: Wprowadzenie. - 1. Życie wspólne. - 2. Życie braterskie. - 3. Życie braterskie we wspólnocie. - 4. Znaczenie życia braterskiego we wspólnocie. - 4.1. Wsparcie w realizacji własnego powołania osoby konsekrowanej. - 4.2. Znak wspólnoty Kościoła w świecie. - Zakończenie.

\section{Wprowadzenie}

Kodeks Prawa Kanonicznego z 1983 r., podając istotne elementy życia konsekrowanego, formułuje po raz pierwszy w historii ustawodawstwa kościelnego definicje trzech rad ewangelicznych: czystości, ubóstwa i posłuszeństwa, a w dalszej kolejności umieszcza w kan. 602 - również po raz pierwszy - pojęcie życia braterskiego zamiast życia wspólnego definiowanego w Kodeksie Prawa Kanonicznego z 1917 r. ${ }^{1}$ W odniesieniu do zakonników KPK/1983 natomiast stosuje określenie życia braterskiego we wspólnocie vitam fraternam in communi ${ }^{2}$, nawiązując $\mathrm{w}$ ten sposób do rozumienia życia wspólnego w początkach życia zakonnego. Druga przyczyną zmiany jest docenienie życia braterskiego przez same osoby konsekrowane, a w tym zwłaszcza zakonników odkrywających na nowo wymiar wspólnoty braterskiej Kościoła będącego sakramentem, czyli znakiem jedności z Bogiem i jedności całego rodzaju ludzkiego ${ }^{3}$. Interesująca jest kwestia, w ja-

1 KPK/1917, kan. 594, §1.

2 KPK/1983, kan. 607 \$2, 619.

${ }^{3}$ LG nr 1; S. GonzÁLEz SILVA, Gli istituti di vita consacrata. Linee generali e norme comuni, Apollinaris 56(1983)538-539. 
kiej relacji, zwłaszcza w odniesieniu do zakonników, pozostają będące obecnie w użyciu terminy ,życie braterskie” oraz „życie braterskie we wspólnocie"4 do stosowanego wcześniej i pojawiającego się nadal sporadycznie w KPK $/ 1983^{5}$ określenia ,życie wspólne”. Czy to ostatnie nie oddawało w pełni istoty życia wspólnot zakonnych, skoro zastappiono je szerszym określeniem życia braterskiego we wspólnocie?

\section{1. Życie wspólne}

Życie wspólne, przejawiające się na zewnątrz w zamieszkaniu razem w tym samym klasztorze, właściwe obecnie instytutom zakonnym i stowarzyszeniom życia apostolskiego, zapoczątkował w IV w. w Egipcie św. Pachomiusz. Była to nowość w stosunku do rozpowszechnionych już w jego czasach indywidualnych (samotniczych) form życia poświęconego Bogu: stanu dziewic, ascetów, pustelników i anachoretów. Sam Pachomiusz w młodości po odbyciu służby wojskowej i przyjęciu chrztu poznawał przez 7 lat u boku pustelnika Palemona życie anachoreckie wypełnione samotnością, pokuta, postem, modlitwą i nocnymi czuwaniami. Wcześniej jako żołnierz doświadczył miłości mieszkających w pobliżu obozu wojskowego chrześcijan, którzy nieśli pomoc głodnym i wyczerpanym żołnierzom. W późniejszym życiu sam świadczył ją innym potrzebującym. Pragną też pomóc żyjącym samotnie mnichom w ich dążeniu do osiagnięcia miłości doskonałej ${ }^{6}$.

Połączenie obu doświadczeń, tj. anachorezy i służby bliźniemu, doprowadziło Pachomiusza do zainicjowania nowej formy monastycyzmu zwanej cenobityzmem (grec.), czyli życia mnichów we wspólnocie. Początkowo wybudował dla mnichów szereg osobnych cel oraz większych pomieszczeń, w których wspólnie modlono się, spożywano posiłki i wykonywano pewne prace. Przebywanie razem sprzyjało nawiązywaniu wzajemnych relacji i wymianie doświadczeń, które okazywały się pomocne w dążeniu do doskonalszej miłości Boga i bliźniego ${ }^{7}$. Członkowie wspólnoty pachomiańskiej nie byli już mnichami

4 KPK/1983, kan. 607 § 2.

$5 \mathrm{KPK} / 1983$, kan. $665 \S 1$.

${ }^{6}$ A. De VogüÉ, Il monachesimo antico, Dizionario degi Istituti di Perfezione, t. X, Roma 2003, kol. 282-286 (odtąd: DIP).

7 Tamże, kol. 282-286; S. TESTA BAPPEnHeIM, La vita fraterna. Fenotipi storico-canonistici dei consacrati a Dio, Lecce 2006, s. 28-29; J.M., LozANo, La comunità reli- 
w pierwotnym tego słowa znaczeniu, ponieważ, zamieszkując razem,

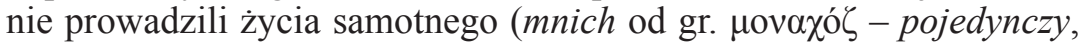
samotny, jedyny, bezludny), lecz nazywali się braćmi, podobnie jak pierwsi chrześcijanie zgodnie z nauczaniem Chrystusa ${ }^{8}$. We wspólnym przebywaniu, dążeniach i wzajemnych relacjach odkrył Pachomiusz istotę braterskiej wspólnoty istniejącej już niegdyś w zgromadzonej wokół Chrystusa grupie Apostołów i uczniów, a następnie w gminie chrześcijan w Jerozolimie. Sposób życia osób przynależących do cenobium miał odzwierciedlać owo zjednoczenie chrześcijan z Bogiem i między sobą, stąd wspólnoty pachomiańskie nazywano często drogą Apostołów ${ }^{9}$. Szybko też pojawiła się konieczność wprowadzenia pewnej dyscypliny w sposobie bytowania mnichów, ujętej następnie w Regule, oddającej ducha wspólnoty, która nie może trwać bez pewnych uregulowań prawnych. Był to z pewnością wymóg istnienia wspólnoty, ponieważ żaden $\mathrm{z}$ wielkich zakonodawców nie pozostawił swych uczniów bez tego rodzaju przepisów. Członkowie wspólnot $\mathrm{z}$ kolei dobrze zdawali sobie sprawę $\mathrm{z}$ tego, że zasady zawarte $\mathrm{w}$ regule służyły nie tylko zachowaniu porządku zewnętrznego, ale przede wszystkim miały sprzyjać doświadczeniu obecności Boga i nawiązaniu głębszej z Nim relacji we wzajemnej miłości braci. Trzeba w tym miejscu zauważyć, że relacje braci miały znaczenie drugorzędne, natomiast najważniejsze było życie wspólnoty w odniesieniu do Boga, jej wymiar wertykalny ${ }^{10}$. Św. Pachomiusz na wzór Kościoła, który miał pasterzy powołanych przez Boga, również ustanowił w swych wspólnotach przełożonych będących przedstawicielami Boga ${ }^{11}$. Pierwsza wspólnota pachomiańska zamieszkała w opuszczonej wiosce i wciąż się powiększała wraz z napływem nowych kandydatów. Nieustanne trwanie na modlitwie, podobnie jak wspólnoty jerozolimskiej, wy-

giosa nel suo sviluppo storico, w: AA.VV., Vita comunitaria, Milano 1979, s. 11-12; J.M. LozAno, La comunità pacomiana dalla comunione all'istituzione, Claretianum 15(1975)240.

${ }^{8}$ Mt 23, 8; J.M. LozAno, La comunità pacomiana ..., s. 250; S. Testa BAPPENHeIM, La vita fraterna..., s. 29.

9 A. DE VoGÜÉ, Il monachesimo antico..., kol. 288.

${ }^{10}$ A. DE Vogüé, Sguardi sul monachesimo, Bologna 2006, s. 41.

11 A. DE VogüÉ, Il monachesimo antico..., kol. 287. 
magało oddzielania od świata i samotności, zaistniała więc potrzeba ogrodzenia się murem i zamykania go na czas sprawowania liturgii ${ }^{12}$.

Kolejni zakonodawcy, tj. św. Bazyli Wielki, św. Augustyn i św. Benedykt z Nursji, tworzyli analogiczne wspólnoty mnichów oparte na podobnych zasadach wspólnego życia, czerpanych z przykładu gminy jerozolimskiej. Aby ukazać rozumienie życia wspólnego przez pierwszych mnichów, należy się odwołać do Dziejów Apostolskich ${ }^{13}$.

Do V wieku uważano powszechnie cenobia za Kościół pierwotny przedłużony w czasie. Świadczyło o tym całkowite ukierunkowanie ich członków na Boga, cenobityzm bowiem nie zasadzał się na wspólnym, zgodnym zamieszkaniu, ale przede wszystkim na porzuceniu świata i wspólnym poszukiwaniu Boga, Jego woli. Św. Bazyli Wielki pisał, że mnisi zjednoczeni w imię Chrystusa wtedy dostępują łaski Jego obecności pośród siebie, gdy dobrze poznają wolę Tego, który ich zjednoczył we wspólnotę. Chrystus, widząc dwóch lub trzech zgromadzonych w jedno przez wiarę w Niego, idzie i zamieszkuje między nimi, pociagany ich wiarą i sprowokowany ich jednością ${ }^{14}$. Jak męczennicy w więzieniu, tak i mnisi w klasztorze dawali świadectwo swej przynależności do innego świata ${ }^{15}$. O prymacie Boga świadczyło ich trwanie w nieustannej modliwie indywidualnej oraz wspólnotowej, odmawianej co 3 godziny, a także uczestnictwo w Eucharystii jako

12 J.M. Lozano, La comunità religiosa..., s. 240.

13 Dz 2, 42-47: „Trwali oni w nauce Apostołów i we wspólnocie, w łamaniu chleba i w modlitwach. Bojaźń ogarniała każdego, gdyż Apostołowie czynili wiele znaków i cudów. Ci wszyscy, co uwierzyli, przebywali razem i wszystko mieli wspólne. Sprzedawali majątki i dobra i rozdzielali je każdemu według potrzeby. Codziennie trwali jednomyślnie w świątyni, a łamiąc chleb po domach, przyjmowali posiłek z radością i prostotą serca. Wielbili Boga, a cały lud odnosił się do nich życzliwie. Pan zaś przymnażał im codziennie tych, którzy dostępowali zbawienia; Dz 4, 32-37: Jeden duch i jedno serce ożywiały wszystkich wierzących. Żaden nie nazywał swoim tego, co posiadał, ale wszystko mieli wspólne. Apostołowie z wielką mocą świadczyli o zmartwychwstaniu Pana Jezusa, a wszyscy oni mieli wielką łaskę. Nikt z nich nie cierpiał niedostatku, bo właściciele pól albo domów sprzedawali je i przynosili pieniądze [uzyskane] ze sprzedaży, i składali je u stóp Apostołów. Każdemu też rozdzielano według potrzeby. Tak Józef, nazwany przez Apostołów Barnabas, to znaczy «Syn Pocieszenia», lewita rodem z Cypru, sprzedał ziemię, którą posiadał, a pieniądze przyniósł i złożył u stóp Apostołów"; A. DE VoGÜÉ, Sguardi sul monachesimo..., s. 43.

14 Św. Bazyli Wielki, Reguły krótsze, pytanie 225 w: Tenże, Pisma ascetyczne, t. 2. Źródła monastyczne t. 6: (red. M. Starowieyski), Kraków 1995, s. 370.

15 A. DE VogüÉ, Sguardi sul monachesimo..., s. 20. 
wyraz jedności ducha i serc. Trwanie w nauce Apostołów i słuchanie Słowa Bożego odbywało się nie tylko w czasie lectio, ale przedłużało się na cały dzień - także na czas wykonywanej pracy, która nie stanowiła wcale przeszkody, lecz była pomocą w głębszym rozumieniu Słowa Bożego. Modlitwa i słuchanie Słowa wymagały zachowania ciszy i skupienia, klauzury i praktyk acetycznych. Duch ubóstwa skłaniał mnichów do nienazywania swoim tego, co posiadali, do dzielenia się dobrami materialnymi tak, że nikt nie cierpiał niedostatku, a każdemu rozdzielano według potrzeby. Ducha ubóstwa wyrażało również noszenie ubogiego stroju ${ }^{16}$. Tak więc zewnętrzne wymogi wspólnego zamieszkania - tj. wykonywana wspólnie praca, dzielenie się dobrami materialnymi, wspólne spożywanie posiłków, posłuszeństwo wszystkich jednej regule i ustanowionym przełożonym, nieustanna modlitwa, udział w Eucharystii - służyły osiagnięciu przez poszczególnych braci dóbr niewidzialnych, wewnętrznych ${ }^{17}$.

$\mathrm{Z}$ biegiem czasu zatracał się wewnętrzny wymiar życia wspólnego, a uwaga zakonników przesuwała się w stronę zewnętrznych unormowań prawnych wspólnoty, które przybierały znaczenie bardziej formalne niż duchowe. Pilne zachowywanie zewnętrznych przejawów życia we wspólnocie, dbanie o ład i porządek nazywano obserwancją zakonną ${ }^{18}$. Sobór Trydencki życie we wspólnocie sprowadził w zasadzie do przepisów zakazujących wychodzenia z klasztoru zwłaszcza mniszkom, co wiązało się z obowiązkiem zachowania przez nie ścisłej klauzury. Sobór uznał życie wspólne za niezbędne dla życia zakonnego i powiązał je ściśle ze ślubem ubóstwa, kładąc duży nacisk na zachowanie jednakowego porządku dnia, równość i ubóstwo wszystkich w zakresie pożywienia, odzieży i korzystanie z takich samych sprzętów, unikanie wszystkiego, co wykracza poza określony stan ubóstwa, ale jednocześnie zapewnienie zakonnikom tego, co jest dla nich niezbędne. Ojcowie soborowi zalecili także rezygnację zakonników z posiadania na własność dóbr i używanie dóbr wspólnych zgodnie ze

${ }^{16}$ Tamże, s. 19-38; J. Galot, La condivisione nella comunità, Vita Consacrata 22(1986)101-116.

${ }_{17}$ Mt 18, 20: „Bo gdzie są dwaj albo trzej zebrani w imię moje, tam jestem pośród nich".

${ }_{18}$ V. DE PAolis, La vita consacrata nella Chiesa (edizione rivista e ampliata a cura di Vincenzo Mosca), Venezia 2010, s. 308. 
ślubem ubóstwa i w zależności od przełożonych. Tych ostatnich zobowiązano do troski o przestrzeganie postanowień soborowych ${ }^{19}$.

W kolejnych wiekach dbano o skrupulatne zachowywanie wymienionych elementów życia wspólnego, rozszerzając je nawet na wymóg jednolitego zachowania zakonników (sposób poruszania się, postawę i gesty $\mathrm{w}$ czasie modlitwy itp. ${ }^{20}$. Także w nowych zgromadzeniach zakonnych, powstających zwłaszcza w XIX w., życie wspólne ujmowano zasadniczo w wymiarze zewnętrznym. Potwierdzają to przepisy wydane w 1901 r. przez Kongregację Zakonników dla tych zgromadzeń $^{21}$, które skupiały się jeszcze bardziej na zewnętrznym sposobie bycia. To z kolei było konsekwencją nakazywania przez ówczesne dyrektywy ograniczania się w konstytucjach powstających zgromadzeń tylko do elementów prawnych. Nie wolno było umieszczać w konstytucjach jakiegokolwiek rozwinięcia teologicznego, a więc także odwoływać się do fragmentów Pisma św., cytatów z pism Ojców Kościoła oraz soborów, tak przecież istotnych dla oddania głębszej istoty życia wspólnego, tzn. braterskiego jego wymiaru.

Kodeks z 1917 r. kontynuował wcześniejsze ustawodawstwo dotyczące życia wspólnego i w kan. 594 §1 podał, że w instytutach zakonnych powinno być przez wszystkich zachowane życie wspólne także w tym, co dotyczy wyżywienia, ubioru i używania sprzętów. W innych kanonach $(554,569,587,594)$ życie wspólne zostało precyzyjniej określone w kwestii klauzury, zachowania ślubów i odbywania praktyk zakonnych. Wynika z nich, że życie wspólne sprowadzono do jednolitości sposobu bycia i wymagań dla wszyskich członków danego zgromadzenia lub zakonu. Ujęto je w znaczeniu prawnym i dyscyplinarnym bez uwzględnienia odmienności wynikającej chociażby z charyzmatów poszczególnych zgromadzeń. Przepisy kodeksowe były literalnie przenoszone do kon-

${ }^{19}$ H.M. STAmm, Vita commune. XI. Dal concilio di Trento a oggi, DIP, t. X, Roma 2003, kol. 326 .

${ }^{20}$ Mt 23, 25 „Biada wam, uczeni w Piśmie i faryzeusze, obłudnicy! Bo dbacie o czystość zewnętrznej strony kubka i misy, a wewnątrz pełne są one zdzierstwa i niepowściągliwości".

${ }^{21}$ Sacra Congregatio Episcoporum et Regularium, Normae, secundum quas S. Congr. Episcoporum et Regularium procedere solet in approbandis novis institutis votorum simplicium, 28 iunii 1901, w: T. SCHAEFER, De religiosis ad normam Codicis Iuris Canonici, Roma $1947^{4}$, s. 1102-1134; także w: E. SASTRE SANTOS, El ordenamiento de los institutos de votos simples según las Normae de la Santa Sede (1854-1958), Roma-Madrid 1993, Apéndice documental, nr 57, s. 266-299. 
stytucji, co nadawało im jednakowe jurydyczne brzmienie pozbawione w dużej mierze wymiaru teologicznego także w kwestii uregulowania życia wspólnego 22 .

Sobór Watykański II zgodnie z zasadą powrotu do źródeł pogłębił rozumienie życia wspólnego z punktu widzenia teologicznego i duchowego, wprowadzając w celu oddania jego rzeczywistości pojęcie prawdziwej rodziny zakonnej, zgromadzonej w imię Pana i cieszącej się Jego obecnością ${ }^{23}$. Sobór powtórzył zamysł pierwszych zakonodawców uważających, że życie wspólne zakonników powinno nawiązywać do pierwotnej wspólnoty Kościoła, w której wszyscy byli jednym sercem i jedną duszą. Musi być ono podtrzymywane nauczaniem ewangelicznym, sprawowaniem świętej liturgii, zwłaszcza Eucharystii, opierać się na modlitwie i wspólnocie tego samego Ducha, na wzajemnym okazywaniu sobie przez zakonników szacunku i pomocy ${ }^{24}$.

W czasie odnowy posoborowej we wszystkich instytutach życia zakonnego podejmowano zagadnienie życia wspólnego w nowym ujęciu, o czym świadczy również bogata literatura towarzysząca konkretnym działaniom ${ }^{25}$, podająca nawet szczegółowe projekty życia wspólnotowe$\mathrm{go}^{26}$. Syntezę odnowionego spojrzenia na wspólnotę zakonną przyniósł KPK/1983, który, wprowadzając termin ,braterskie życie we wspólnocie", zwraca większą uwagę właśnie na teologiczny, a więc duchowy obszar życia wspólnego ${ }^{27}$.

\section{2. Życie braterskie}

$\mathrm{Z}$ analizy historycznej wynika, że wszystkie powstające na przestrzeni wieków wspólnoty monastyczne, a następnie zakonne - od

${ }^{22}$ B. SECONDIN, La vita fraterna in comune: per un nuovo impulso, Consacrazione e Servizio, 41/39(1992)21; J. BeYER, Il diritto della vita consacrata, Milano 1989, s. 91; G. PAsquale, Autonomia e corresposabilità dei religiosi nel Codex Iuris Canonici, s. 282283.

${ }^{23}$ PC 15; H.M. Stamm, Vita commune. XI. Dal concilio di Trento a oggi. V. Il Concilio Vaticano II, DIP, t. X, Roma 2003, kol. 332.

24 PC 15.

25 Por. indeks analityczny artykułów zawartych w Vita Consacrata w latach 19651992 dotyczący wspólnoty: 28(1992)1014-1016.

${ }^{26}$ G. Scarvaglieri, Progetto di vita comunitaria, Consacrazione e Servizio 4/30(1981)29-34: Tenże, Metodologia per un progetto di vita comunitaria, Consacrazione e Servizio 5/30(1981)9-17.

27 KPK/1983, kan. 602. 
pachomiańskiej, poprzez benedyktyńskie, aż do tych braterskich św. Franciszka ${ }^{28}$ oraz wspólnot jezuickich - mimo odmiennej organizacji zewnętrznej życia członków nawiązywały do ducha wspólnoty jerozolimskiej opisanej w Dziejach Apostolskich, wyrażając tym samym swoistą tęsknotę za życiem Apostołów ${ }^{29}$. Członkowie tych wspólnot dobrze zdawali sobie sprawę ze znaczenia braterstwa dla ich osobistych relacji z Bogiem ${ }^{30}$. Prawdę tę potwierdzają współczesne dokumenty kościelne, w których wyjaśnia się jednocześnie rozumienie życia braterskiego obecnie. Podkreślają one, że pierwsze wspólnoty monastyczne wpatrzone były we wspólnotę uczniów z ich Mistrzem oraz tę jerozolimską jako ideał życia. I podobnie jak Kościół pierwotny miał jedno serce i jedną duszę, tak i mnisi zgromadzeni wokół opata i pod jego duchowym przewodnictwem zobowiązywali się żyć w radykalnej wspólnocie dóbr materialnych i duchowych w jedności zapoczątkowanej przez Chrystusa. Wspólnoty zakonne powstawały więc nie ,z woli ciała ani z krwi”, nie z osobistych sympatii ich członków, ale z tęsknoty za Bogiem. Dlatego powinny być znakiem tego, że pierwszeństwo $\mathrm{w}$ nich ma miłość do Boga i bliźniego ${ }^{31}$. W adhortacji apostolskiej Jana Pawła II Vita consecrata dodano, że braterstwo domaga się oddania wszystkiego wspólnocie: dóbr materialnych i doświadczeń duchowych, talentów i pomysłów, a także ideałów apostolskich i posługi miłosierdzia. Dla życia braterskiego jest istotne, że moc Ducha Świętego, która staje się udziałem jednego, przechodzi zarazem na wszystkich. Każdy korzysta nie sam z własnego daru, ale pomnaża go i udziela innym, ciesząc się owocami cudzych darów jak własnymi. Taki rodzaj braterstwa znajduje swój pierwowzór w jedności i harmo-

${ }^{28}$ G. FIORINI, La vita fraterna nell'esperienza francescana. Excerptum theseos ad Doctoratum in S. Theologia. Ponteficia Universitas Lateranensis, Roma 1995.

${ }_{29}$ P.G. CABRA, Riproporre lo stile della «vita degli apostoli» (Lineamenta $\mathrm{nr}$ 9), Vita Consacrata 29(1993)701-702.

30 J.M. LozAno, La comunità religiosa ..., s. 9-41; R. GrazIANO, La trasformazione della vita comunitaria religiosa nel tempo dell'aggiornamento, Roma 1985, s. 163.

31 Congregazione per gli Istituti di Vita Consacrata E le Società di Vita Apostolica, La vita fraterna in comunità, "Congregavit nos in unum Christi amor», 2 februarii 1994, Libreria Editrice Vaticana 1994, nr 1, 10; tekst polski, KongregacjA Instytutów Życia Konsekrowanego i Stowarzyszeń Życia Apostolskiego, Instrukcja Życie braterskie we wspólnocie, w: Życie konsekrowane w dokumentach Kościoła. Od Vaticanum II do Ripartire da Cristo (red. K. Wójtowicz), Kraków 2003², s. 499-548 (odtąd: Congregavit nos). 
nii Osób Trójcy Świętej. Duch Święty wprowadza zakonnika w komunię z Ojcem i Synem, która jest źródłem życia braterskiego ${ }^{32}$.

KPK/1983 podaje definicję życia braterskiego we wspomnianym już kan. 602, określając je jako zjednoczenie wszystkich członków instytutu w szczególną jakby rodzinę w Chrystusie, i powinno być ono tak określone w prawodawstwie i tradycji instytutu, aby mogło stanowić wsparcie dla każdego z jego członków w realizacji własnego powołania. I dodaje się, że prawdziwe braterstwo osób konsekrowanych W miłości powinno stać się przykładem powszechnego pojednania w Chrystusie ${ }^{33}$.

Z powyższej definicji wynika, że sposób życia braterskiego właściwy jest także instytutom świeckim oraz indywidualnym formom życia konsekrowanego, gdyż z kościelnej wspólnoty nie wyłamują się nawet pustelnicy pogrążeni w samotności ani dziewice konsekrowane, żyjące w świecie i służące Kościołowi partykularnemu oraz powszechnemu. Życie to dotyczy również konsekrowanych wdów i wdowców. Ale ze specjalną intensywnością jest ono rozwijane w instytutach zakonnych i stowarzyszeniach życia apostolskiego, których członkowie na co dzień mieszkają pod jednym dachem i mają szczególną możliwość na skutek ciagłego przebywania ze sobą realizacji podstawowego przykazania, tj. miłości ${ }^{34}$. Stanowiło ono istotę życia wspólnego już w czasach św. Pachomiusza, na co wskazują przepisy jego Reguły,

32 JoAnnes Paulus II, Adhortatio apostolica post-synodalis, De Vita consecrata euisque missione in Ecclesia ac mundo, "Vita consecrata», 25 martii 1996, nr 42, AAS 88(1996)377-486; tekst polski: JAN PAWE⿺ II, Posynodalna adhortacja apostolska o życiu konsekrowanym i jego misji w Kościele i świecie «Vita consecrata», WarszawaZąbki 1996; F. CIARDI, Il coraggio della comunione. Vie nuove per la vita religiosa, 19-31.

33 J. KaŁowsKI, Życie braterskie we wspólnocie. Studium prawno-historyczne, Warszawa 1999, s. 175-176.

${ }^{34}$ Mt 22, 36-39: „Nauczycielu, które przykazanie w Prawie jest największe?” On mu odpowiedział: «Będziesz miłował Pana Boga swego całym swoim sercem, całą swoją duszą i całym swoim umysłem. To jest największe i pierwsze przykazanie. Drugie podobne jest do niego: Będziesz miłował swego bliźniego jak siebie samego. Na tych dwóch przykazaniach opiera się całe Prawo i Prorocy»"; Rz 13, 8-10: „Nikomu nie bądźcie nic dłużni poza wzajemną miłością. Kto bowiem miłuje bliźniego, wypełnił Prawo. Albowiem przykazania: Nie cudzołóż, nie zabijaj, nie kradnij, nie pożądaj, i wszystkie inne - streszczają się w tym nakazie: Miłuj bliźniego swego jak siebie samego! Miłość nie wyrządza zła bliźniemu. Przeto miłość jest doskonałym wypełnieniem Prawa". 
z których większość to wykroczenia przeciwko miłości ${ }^{35}$. Warto zauważyć, że życie braterskie określa się dziś także mianem teologii wspólnoty lub duchowością wspólnoty.

\section{3. Życie braterskie we wspólnocie}

Niniejszy artykuł nie ma celu całościowego ujęcia zagadnienia życia braterskiego we wspólnocie, zwłaszcza że Kongregacja Instytutów Życia Konsekrowanego i Stowarzyszeń Życia Apostolskiego poświęciła mu cały dokument pt. Życie braterskie we wspólnocie. Congregavit nos in unum Christi Amor, wydany w 1994 r. Stąd kwestia ta została ograniczona tylko do ukazania życia braterskiego we wspólnocie głównie w ujęciu KPK/1983 r. Wydaje się, że prawidłowo oddano w nim rozumienie braterstwa we wspólnocie monastycznej właściwe tradycji - np. jako rodziny w ujęciu św. Bazylego czy szkoły uczniów zgromadzonych wokół Mistrza według św. Benedykta. Dzięki wprowadzeniu pojęcia życia braterskiego normy KPK/1983 określające życie wspólne właściwe zakonnikom i członkom stowarzyszeń życia apostolskiego - oprócz ukazania go w wymiarze prawnym, zewnętrznym - kłada także nacisk na wymiar duchowy, wewnętrzny wspólnoty, nawiązując w ten sposób do życia pierwszych wspólnot zakonnych. Podkreślaja, że życie we wspólnocie według ujęcia zawartego w KPK/1917, czyli wspólne zamieszkanie $\mathrm{w}$ domu zakonnym, przestrzeganie przepisów prawa własnego, wspólna kasa, jednolity sposób życia, mają sprzyjać życiu braterskiemu ${ }^{36}$. Z połączenia obu ujęć wynika, że życie braterskie we wspólnocie polega na wspólnym zamieszkaniu w jednym domu prawnie ustanowionym pod władzą przełożonego wyznaczonego zgodnie z prawem. A że życie wspólnoty musi koncentrować się wokół Eucharystii, w domu powinna być kaplica. Prawodawca postanawia, że zakonnicy mają obowiązek przebywania we własnym domu zakonnym, ale wymienia też sytuacje, które usprawiedliwiają ich prawną nieobecność. Duchowość wspólnoty dobrze oddaje kodeksowy opis posługi przełożonych i sposób jej sprawowania w duchu służby braciom, przy czym istotne jest tu z naszego punktu widzenia wyliczenie obowiązków ascetyczno-duchowych przełożonego wzglę-

35 Vita consecrata, nr 42; Św. PAchomiusz, Reguła-Przykazania i orzeczenia, nr 160-176, w: Pachomiana latina. Źródła monastyczne, t. 11, (red. M. Starowiejski) Kraków 1996, s. 165-169; S. Testa BApPEnHeim, La vita fraterna ..., s. 29.

36 Congregavit nos, $\mathrm{nr} 3$. 
dem jego współbraci ${ }^{37}$. Jeżeli do wymienionych elementów doda się definicje poszczególnych rad ewangelicznych nie tylko prawne, ale mające również charakter teologiczny, i odzwierciedlenie charyzmatu instytutu w ramach patrimonium, czyli dziedzictwa instytutu, oraz liczne obowiązki zakonników wyliczone przez prawodawcę-dostrzec można, że obowiązujące prawodawstwo, bazujące na doświadczeniu posoborowej odnowy, nie mogło lepiej oddać istoty życia braterskiego we wspólnocie. Ukazuje ono styl życia zakonników różny od dawnego zuniformizowanego - szarego i surowego ${ }^{38}$.

W tym miejscu rozważań rodzi się pytanie: czy wysiłek posoborowej odnowy oraz ten związany z promulgacją KPK/1983, zmierzający do właściwego ukazania życia braterskiego zwłaszcza we wspólnocie, pomógł współczesnym zakonnikom w osiągnięciu ideału wspólnoty jerozolimskiej? Czy przyczynił się do tego, że życie braterskie we wspólnocie staje się przestrzenią teologalną, w której można doświadczyć mistycznej obecności Chrystusa?

Istota wspólnoty polega na tym, że daje ona sposobność spotkania z Bogiem, stanowi miejsce pozwalające na doświadczenie Boga obecnego w braciach i siostrach. Jest czymś, w co trudno nam, współczesnym, uwierzyć, podczas gdy w kościele pierwotnym istniała żywa świadomość owego doświadczenia Boga ${ }^{39}$. Wspólnota zakonna to miejsce, gdzie jest się powołanym do bycia bratem lub siostrą ${ }^{40}$.

\section{Znaczenie życia braterskiego we wspólnocie}

Już mnichom pachomiańskim wspólnota, którą tworzyli, miała służyć pomocą w osiagnięciu doskonałej miłości do Boga i całkowitemu oddaniu się Jemu, a dążenie to, ożywiające poszczególnych mnichów, sprawiało, że cała ich wspólnota postrzegana była nie jako znak Kościoła, lecz przedłużenie życia pierwszego Kościoła w Jerozolimie. Podobnie i dziś najważniejszym dążeniem każdej braterskiej wspólnoty powinna być pomoc poszczególnym jej członkom w tym, aby byli

37 KPK/1983, kan. 602, 607, 608, 618-619, 665, 696, 740.

38 B. SECONDIN, La vita fraterna in comune: per un nuovo impulso, Consacrazione e Servizio, 41/39(1992)25.

39 C. Andrade, Verso una spiritualità comunitaria, w: AA.VV., Il coraggio della comunione. Vie nuove per la vita religiosa, Roma 1993, s. 13.

40 J. Aubry, Teologia della vita consacrata, w: Vita consacrata, un dono del Signiore alla sua Chiesa, Torino 1993, s. 353. 
wierni swemu powołaniu, a prowadząc życie braterskie w miłości, stawali się dla świata widzialnym znakiem Kościoła ${ }^{41}$.

\subsection{Wsparcie w realizacji własnego powołania osoby konsekrowanej}

W dokumentach Kościoła, aby oddać relacje braterskie we wspólnocie, często nazywa się ją ,prawdziwą rodziną” (PC 15; EE 19) oraz „szczególną rodziną w Chrystusie” (KPK/1983, kan. 602). Wstępując więc do instytutu, kandydat przyjmuje miejsce syna w rodzinie i czuje się zdolny do oddania siebie tej rodzinie, oczekując, że ona pomoże mu rozwinąc jego osobowość i relacje z Chrystusem. Do prawdziwej rodziny upodabnia wspólnotę zakonną i wspólnotę w stowarzyszeniu życia apostolskiego fakt, że jako sposób życia istnieje ona nieustannie i widzialnie w odróżnieniu od spotykających się periodycznie np. w czasie niedzielnej Mszy św. wspólnot parafialnych oraz tych właściwych instytutom świeckim ${ }^{42}$. Stały i rodzinny charakter wspólnoty zakonnej pozwala na nawiązywanie wewnątrz niej głębokich relacji osobowych, podobnie jak w rodzinie opartej na więzach krwi. Poza tym członkowie wspólnoty zakonnej są do niej inkorporowani przez profesję zakonną, a ta jest po sakramencie chrztu drugim nawróceniem i bardziej radykalnym poświęceniem się Chrystusowi, a w Nim Bogu w Duchu Świętym. Ten wymiar relacji z Bogiem powinien kształtować jednocześnie szczególne relacje osobowe ze współbraćmi. Wspólnota jest rodziną zjednoczoną w imię Chrystusa, a jej istoty nie wyczerpują spotkania związane ze wspólnie wykonywanymi pracami i apostolatem. Nie służą one tylko wymianie poglądów i idei, lecz każdy uczestnik dialogu pozwala poznać się innym, wyrażając samego siebie, jako osoba wolna, naznaczona niepowtarzalną łaską Boga. Także przełożony wspólnoty powinien być dla podwładnych nie tylko ojcem, ale przede wszystkim bratem, przy czym relacja braterstwa nie likwiduje funkcji władzy ${ }^{43}$. Jest to więc wspólnota, która potrafi nie tylko dzielić się dobrami materialnymi, ale także duchowymi.

Styl życia wspólnoty powinien służyć przede wszystkim osiagnięciu pełnej dojrzałości i rozwojowi jej członków ${ }^{44}$, ponieważ wspólno-

41 D.J. AndRÉs, Il diritto dei religiosi. Commento esegetico al codice, Roma 1999, s. 50.

42 V. Gambari, Comunità religiosa, comunità di persone, Brescia 1968, s. 34-35.

43 Tamże, s. 72-73.

${ }^{44}$ LG 43: „...rozmaite rodziny zakonne, które pomnażają to, co służy zarówno pożytkowi ich członków, jak i dobru całego Ciała Chrystusowego. Rodziny te bowiem 
ta jest odpowiedzialna za nich i ich dążenie do nawiązania osobowej relacji z Chrystusem, stąd nie może ona poświęcać ich życia i dobra duchowego dla prowadzonych przez instytut czy stowarzyszenie dzieł apostolatu. Taka sytuacja byłaby nieuczciwością wobec Kościoła, który zatwierdził dany instytutu o określonym charyzmacie, a realizacja tego ostatniego z pewnością nie polega tylko na pomnażaniu zysków wspólnoty dzięki pracy jej członków z jednoczesnym zaniedbywaniem rozwoju ich relacji z Bogiem.

\subsection{Znak wspólnoty Kościoła w świecie}

Instytuty życia konsekrowanego i stowarzyszenia życia apostolskiego powstają w Kościele i dla Kościoła ${ }^{45}$, a życie ich członków powinno być dla wierzących i niewierzących wyraźnym znakiem życia braterskiego we wspólnocie na wzór Kościoła pierwotnego. Stąd ich istota nie polega na przepowiadaniu, prowadzeniu dzieł apostolskich czy innego typu działalności (a często można odnieść takie wrażenie, przyglądając się z bliska wspólnotom zakonnym) i nie tego powinny być wyrazem, lecz przede wszystkim uzewnętrznieniem wymiaru teologicznego braterstwa, tego, że jeden duch i jedno serce ożywia wszystkich, a Chrystus zamieszkuje wśród nich. Mają być znakiem zjednoczenia z Bogiem umiłowanym nade wszystko, świadectwem całkowitego oddania się realizacji woli Bożej ${ }^{46}$. Ludzie przyglądający się wspólnocie jerozolimskiej odnosili się do jej członków życzliwie, ponieważ ci wielbili Boga, a nie dokonywali wielkich dzieł ${ }^{47}$.

dają członkom swym pomoc polegającą na umocnieniu ich w danym sposobie życia, na wypróbowanej nauce prowadzącej do osiągnięcia doskonałości, na wspólnocie braterskiej w służbie Chrystusowej i na umocnionej przez posłuszeństwo wolności, tak iż mogą oni bezpiecznie wypełniać swe śluby zakonne i zachowywać je wiernie oraz czynić radośnie postępy na drodze miłości”. S. BISIGNANo, La formazione comunitaria nella vita religiosa apostolica, Vita Consacrata 22(1986)425-429.

${ }^{45}$ LG 44; E. GAMBARI, Consacrati e inviati. Spiritualità e diritto della vita consacrata, Milano 1979, s. 131.

46 Kongregacja Zakonów i Instytutów Świeckich, Zakonnicy i promocja ludzka «Optiones evangelicae», nr 24, w: Życie konsekrowane w dokumentach Kościoła. Od Vaticanum II do Ripartire da Cristo (red. K. Wójtowicz), Kraków 2003², s. 221 (odtąd: ZPN); M. Thurian, Taizé. Una esperienza di vita cominitaria, w: AA. VV., Vita comunitaria, Milano 1979, s. 251.

47 Dz 2, 47. 
W dekrecie soborowym Perfectae caritatis wyjaśnia się, że wspólnota zakonna wtedy gromadzi się w imię Pana i cieszy się Jego obecnością, kiedy w sercach jej członków rozlana jest przez Ducha Świętego miłość ${ }^{48}$. Wówczas przejawy wzajemnej miłości, dyspozycyjności, dialogu, ludzkiego zrozumienia i poświęcenia uzewnętrzniają rzeczywistość głębszą i tajemniczą, będącą zapowiedzą przyszłego świata, tj. tajemnicę Trójcy Świętej, a więc wspólnoty życia z Ojcem w Synu. Wspólnota zakonna nie jest poszukiwaniem jakiejkolwiek doskonałości duchowej, lecz powinna świadczyć o wspólnocie życia, jaką ukazał Bóg w tajemnicy zbawienia wypełnionej przez Chrystusa ${ }^{49}$. Wspólnota zakonna to tajemnica, ale też sakrament, a więc rzeczywistość i znak obecności Boga w codziennym życiu osób tworzących wspólnotę żyjącą Ewangelią ${ }^{50}$.

W dokumencie Zakonnicy i promocja ludzka wydanym w 1980 r. nazwano zakonników zobowiązującym terminem „eksperci komunii”, a w adhortacji Vita consecrata „mistrzami komunii”, przypominając, że powinni być w Kościele i świecie budowniczymi wspólnoty oraz znakiem tejże komunii ${ }^{51}$. Czy tak jest istotnie? Czy samym byciem ukazują w konkretny sposób owoce „nowego przykazania”? Czy budzą w innych wiernych tęsknotę za braterstwem bez granic? ${ }^{52}$

Jak daleko życie braterskie we wspólnocie odbiega w rzeczywistości od tego określanego mianem rodziny, wiedzą ci, którzy je praktykują, i z pewnością czują się niejednokrotnie zażenowani określaniem ich „ekspertami” czy „mistrzami komunii”.

\section{Zakończenie}

Okres odnowy posoborowej i rozwój eklezjologii przyczyniły się do odkrycia na nowo sensu wspólnoty zakonnej w wymiarze mistycznym i teologicznym dzięki wprowadzeniu pojęcia życia braterskiego, właściwego skądinąd wszystkim formom życia konsekrowanego. Już ponad 40 lat trwają próby podejmowania głębszego życia braterskiego we wspólnotach na wzór tych pierwszych jerozolimskich, pa-

48 PC 15; Rz 5, 5; Mt 18,20.

49 V. Gambari, Comunità religiosa..., s. 16-18, 25.

50 Tamże, s. 16.

51 ZPN, nr 24; Vita consecrata, nr 46; S. Bisignano, La formazione comunitaria..., s. 423.

52 Vita consecrata, $\mathrm{nr} 85$. 
chomiańskich, bazyliańskich, augustyńskich czy benedyktyńskich. Teoretycznie omówiono i opracowano dość precyzyjnie ów model życia, łącznie z jego projektami. Jednak praktyczna realizacja owych rad i projektów nie wygląda najlepiej. Co więcej, życie zakonne coraz wyraźniej traci swoje znaczenie symbolu wspólnoty kościelnej, ponieważ nie pociaga innych do wejścia w nią. Wydaje się, że problemem całego procesu odnowy życia braterskiego są braki w formacji osób konsekrowanych, uniemożliwiające im życie prawdą ewangelicznego braterstwa we wspólnocie.

\section{Fraternal Life and Brotherhood in the community life in the Institutes of Consecrated Life and in Associations of Apostolic Life}

The Code of Canon Law of 1917 regarding the religious person uses the term „community life”. The Code of Canon Law of 1983, however, uses the term „fraternal life in community" ( vitam fraternam in communi) and in general norms for all Institutes of consecrated life gives in Canon 602 a definition „fraternity life”. The goal of this article is to explain the meaning of terms used in both Codes and to show the similarities and differences between them. Striking also is the outdated term "community life". To examine the above - mentioned questions the Author is going back to the beginning of monastic life of cenobites and first monastery founders: St. Pacoima's, St. Basil, St. Augustine and St. Benedict, who were looking for the sense of community life of monks referred to the First Community in Jerusalem. 